\title{
CRIP1 expression is correlated with a favorable outcome and less metastases in osteosarcoma patients
}

\author{
Daniel Baumhoer ${ }^{1,2, *}$, Mareike Elsner ${ }^{3, *}$, Jan Smida2,4, Stephanie Zillmer ${ }^{2}$, Sandra \\ Rauser $^{3}$, Cédrik Schoene ${ }^{3}$, Benjamin Balluff ${ }^{3}$, Stefan Bielack ${ }^{5}$, Gernot Jundt ${ }^{1}$, Axel \\ Walch $^{3, \#}$, and Michaela Nathrath ${ }^{2,4, \#}$ \\ ${ }^{1}$ Bone Tumor Reference Center at the Institute of Pathology, University Hospital Basel, Basel, Switzerland \\ ${ }^{2}$ Clinical Cooperation Group Osteosarcoma, Helmholtz Zentrum Muenchen - National Research Centre for Environment and \\ Health, Neuherberg, Germany \\ ${ }^{3}$ Institute of Pathology, Helmholtz Zentrum Muenchen - National Research Centre for Environment and Health, Neuherberg, \\ Germany \\ ${ }^{4}$ Department of Pediatrics, Technische Universitaet Muenchen and Pediatric Oncology Center, Munich, Germany \\ ${ }^{5}$ Klinikum Stuttgart Olgahospital, Pediatrics 5 - Oncology, Hematology, Immunology, Stuttgart, Germany \\ *Denotes equal contribution \\ \# Shared senior authorship \\ Correspondence to: Daniel Baumhoer, email: dbaumhoer@mac.com
}

Keywords: Osteosarcoma, cysteine-rich intestinal protein 1, CRIP1, prognosis, metastases

Received: December 21,2011, Accepted: December 23, 2011, Published: December 24, 2011

Copyright: @ Baumhoer et al. This is an open-access article distributed under the terms of the Creative Commons Attribution License, which permits unrestricted use, distribution, and reproduction in any medium, provided the original author and source are credited.

ABSTRACT:

Predicting the clinical course of osteosarcoma patients is a crucial prerequisite for a better treatment stratification in these highly aggressive neoplasms of bone. In search of new and reliable biomarkers we recently identified cysteinerich intestinal protein 1 (CRIP1) to have significant prognostic impact in gastric cancer and therefore decided to investigate its role also in osteosarcoma. For this purpose we analyzed 223 pretherapeutic and well characterized osteosarcoma samples for their immunohistochemical expression of CRIP1 and correlated our findings with clinico-pathological parameters including follow-up, systemic spread and response to chemotherapy. Interestingly and contrarily to gastric cancer, we found CRIP1 expression more frequently in patients with long-term survival (10-year survival $73 \%$ in positive vs. $54 \%$ in negative cases, $p=$ $0.0433)$ and without metastases $(p=0.0108)$ indicating a favorable prognostic effect. CRIP1 therefore seems to represent a promising new biomarker in osteosarcoma patients which should be considered for a prospective validation.

\section{INTRODUCTION}

Osteosarcomas are the most common primary malignant tumors of bone generally following an aggressive clinical course [1]. The high rate of systemic spread already at the time of diagnosis explains the efficacy of neoadjuvant and adjuvant chemotherapy and the dismal prognosis after radical surgery alone. However, although 5-year survival rates of up to 50$70 \%$ can be achieved using current treatment protocols, a substantial group of patients with metastatic, recurrent and/or refractory disease is still left without effective treatment options [2, 3]. Analyzing the response to chemotherapy histologically or screening for a set of distinct chromosomal aberrations as we proposed only recently can help in predicting the prognosis of osteosarcoma patients but does not allow a sufficient risk assessment for further treatment stratification [4, 5]. Identifying patients who may not respond to firstline chemotherapy or will have an increased likelihood of developing metastases therefore seems to be a crucial precondition for differentiating high and low risk patients and for designing more individualized therapy regimens. 
Consequently, appropriate and reliant biomarkers are urgently needed.

Cysteine-rich intestinal protein 1 (CRIP1) is a member of the LIM family of zinc-finger proteins which are thought to be involved in cellular growth and differentiation [6, 7]. In several studies, CRIP1 has been proposed as a novel biomarker for breast cancer and its precursor lesions which can be triggered by ERBB2 overexpression [8-10]. Subsequently, upregulation of CRIP1 was also detected in colorectal, cervical and prostatic cancer whereas downregulation was demonstrated in pancreatic carcinoma [11-15]. In gastric cancer, however, we were only recently and for the first time able to demonstrate a pivotal prognostic impact for CRIP1. Overexpression resulted in a significantly shorter overall survival and was identified to represent the strongest prognostic variable besides nodal status [16]. Since the role of CRIP1 in osteosarcomas has not been studied so far, we investigated a set of 223 pretherapeutic tumor samples immunohistochemically and correlated our findings with clinico-pathological parameters to also
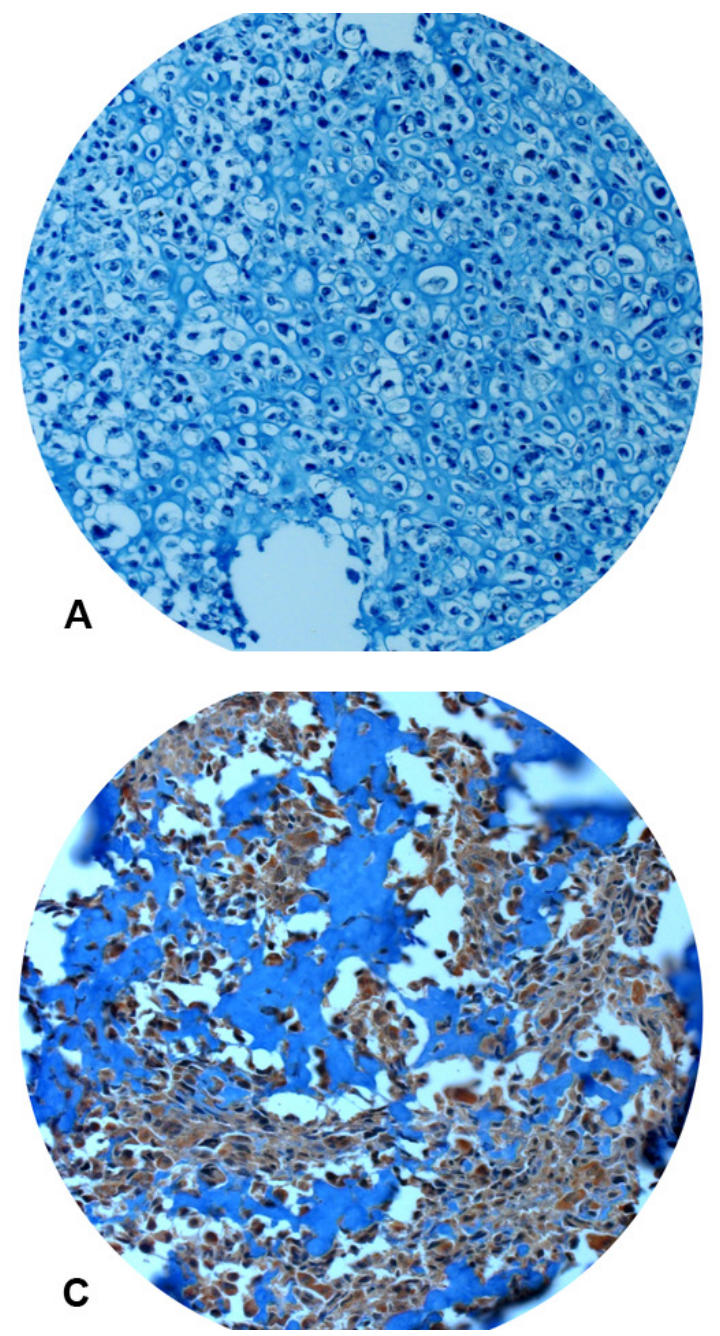

Figure 1: Immunhistochemistry for CRIP1. Absent (A) or focal ( $<50 \%$ positive tumor cells) immunoreactivity was considered negative. Strong and constant staining (B, C) or immunoreactivity in more than $50 \%$ of tumor cells (D) was regarded CRIP1 positive. All pictures $\mathrm{x} 200$.

identify potential prognostic implications of CRIP1 in these aggressive tumors of bone.

\section{RESULTS}

\section{Immunohistochemical expression of CRIP1}

All but four cases demonstrated strong and consistent immunoreactivity for vimentin. Those four cases were excluded from the evaluation leaving a total of 219 osteosarcoma cases for further analysis. CRIP1 expression was considered positive when more than $50 \%$ of tumor cells were immunoreactive for the respective protein (Figure 1). In total, CRIP1 was evaluable in $155 / 219$ (71\%) and considered positive in 69/155 (45\%) cases. Drop out of samples was mainly due to cutting artefacts and/or lack of sufficient amounts of tumor tissue per punch.
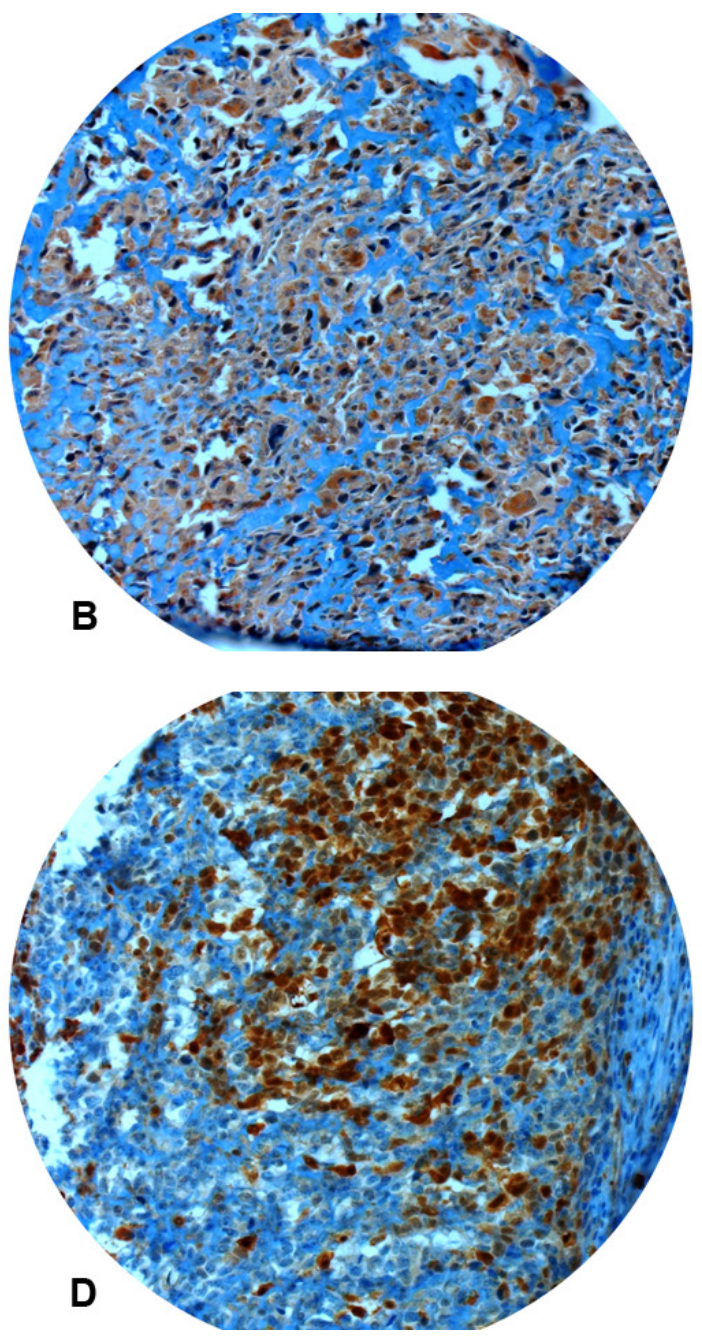
with a favorable outcome and as a statistically significant negative predictor of systemic spread in osteosarcoma. Our findings thus indicate CRIP1 to have tumor type specific oncogenic and tumor suppressor properties needing further pathogenetic clarification. Nevertheless, osteosarcomas are not the first malignant tumors in which a tumor suppressor function of CRIP1 is highly suggestive since also in carcinomas of the pancreas a downregulation of CRIP1 has been reported [14]. However, evidence of prognostic impact of CRIP1 in pancreatic cancer is still lacking.

Taken together, we identified CRIP1 as a new and promising biomarker in osteosarcoma. Although a significant correlation with long-term survival and metastatic spread was identified, an association with response to chemotherapy was not. This phenomenon might be influenced by a relatively high drop out of cases due to technical issues and available response data in only $66 \%$ of cases. Consequently, CRIP1 should be validated prospectively to proof its prognostic reliability and, nonetheless, a potential role in response prediction in osteosarcoma patients.

\section{METHODS}

\section{Tissue samples and patients' characteristics}

All tissue samples were obtained from the archives of the Bone Tumor Reference Center at the University Hospital Basel and the Clinical Cooperation Group Osteosarcoma at the Helmholtz Zentrum Muenchen and comprised cases that were diagnosed between 1974 and 2010. Only samples from patients without prior treatment were included in the study $(n=223)$. Full patients' characteristics are presented in Table 1.

\section{Immunohistochemistry}

Tissue samples $(\mathrm{n}=223)$ were fixed in buffered $4 \%$ formalin, decalcified using EDTA (ethylenediaminetetraacetic acid) if required, embedded in paraffin, and used to construct tissue microarrays as described elsewhere [20]. The resulting blocks were cut into $3 \mu \mathrm{m}$ sections that were transferred to glass slides and subsequently used for immunohistochemistry. To ensure proper immunoreactivity of tumor samples, immunohistochemistry for vimentin was performed

Table 2: Correlation between protein expression and metastases / response to chemotherapy

\begin{tabular}{|l|l|}
\hline Metastases and expression of CRIP1 & p-value \\
\hline Response to chemotherapy and expression of CRIP1 & $\mathbf{0 . 0 1 0 8}$ \\
\hline
\end{tabular}

according to routine protocols (Ventana BenchMark $\mathrm{XT} \AA$, Roche, Basel, Switzerland; CC1 pretreatment; prediluted antibody, clone V9; DAB chromogen). Immunohistochemistry for CRIP1 was also carried out using an automated stainer (Ventana DISCOVERY XT®, Roche, Basel, Switzerland; DAB chromogen). The dilution used for the primary antibody against CRIP1 (AbD Serotec, Oxford, UK) was 1:100.

\section{Evaluation of immunohistochemistry against CRIP1}

Immunoreactivity for CRIP1 was scored semiquantitatively by evaluating the number of positive cells over the total number of cells. Both cytoplasmic and nuclear staining was evaluated. In cases with more than one punch per tumor the average expression was determined for further analyses. Punches that were not completely enclosed on the sections or showed artefacts due to sectioning were excluded from the analysis.

\section{Statistical analyses}

In order to determine the cut-off scores defining immunohistochemical CRIP1 positivity and negativity, receiver operating characteristic (ROC) curve analysis was performed with the endopoint of survival [21]. Survival analyses were carried out using the Kaplan-Meier and Log-rank (Mantel-Cox) test. The differences in protein expression between patients with and without metastases and with good and poor response to chemotherapy were determined using the Mann-Whitney-Test. Only p-values $<0.05$ were considered statistically significant. All analyses were conducted using GraphPad Prism 5.0d (La Jolla, CA, USA) and SPSS 19 (IBM Corporation, Armonk, NY, USA).

\section{DISCLOSURE / CONFLICT OF INTEREST}

We declare that we have no conflict of interest.

\section{ACKNOWLEDGEMENTS / GRANT SUPPORT}

Daniel Baumhoer and Gernot Jundt were supported by the Foundation for the Preservation of the Basel Bone Tumor Reference Center. Jan Smida and Michaela Nathrath are members of the Translational Sarcoma Research Network supported by the BMBF. Michaela Nathrath was, furthermore, supported by the Wilhelm Sander-Stiftung within the Therapieeinheit Knochenund Weichteilsarkome. Stephanie Zillmer was funded by the Helga und Heinrich Holzhauer Stiftung. Axel Walch 
gratefully ackowledges the financial support of the DFG (WA 1656/3-1) and the BMBF (01IB10004E).

\section{REFERENCES}

1. Raymond AK, Ayala AG, Knuutila S. Conventional osteosarcoma. In: Fletcher CDM, Unni KK, Mertens F, eds. World Health Organization Classification of Tumours: Pathology and Genetics of Tumours of Soft Tissue and Bone. IARC Press: Lyon, France 2002:264-270.

2. Bielack SS, Kempf-Bielack B, Delling G, Exner GU, Flege S, Helmke K, Kotz R, Salzer-Kuntschik M, Werner M, Winkelmann W, Zoubek A, Jurgens H, Winkler K. Prognostic factors in high-grade osteosarcoma of the extremities or trunk: an analysis of 1,702 patients treated on neoadjuvant cooperative osteosarcoma study group protocols. J Clin Oncol. 2002; 20: 776-790.

3. Kong C, Hansen MF. Biomarkers in osteosarcoma. Expert Opin Med Diagn. 2009; 3: 13-23.

4. Salzer-Kuntschik M, Delling G, Beron G, Sigmund R. Morphological grades of regression in osteosarcoma after polychemotherapy - study COSS 80 . J Cancer Res Clin Oncol. 1983; 106 Suppl: 21-24.

5. Smida J, Baumhoer D, Rosemann M, Walch A, Bielack S, Poremba C, Remberger K, Korsching E, Scheurlen W, Dierkes C, Burdach S, Jundt G, Atkinson MJ, Nathrath M. Genomic alterations and allelic imbalances are strong prognostic predictors in osteosarcoma. Clin Cancer Res. 2010; 16: 4256-4267.

6. Lanningham-Foster L, Green CL, Langkamp-Henken B, Davis BA, Nguyen KT, Bender BS, Cousins RJ. Overexpression of CRIP in transgenic mice alters cytokine patterns and the immune response. Am J Physiol Endocrinol Metab. 2002; 282: E1197-1203.

7. Cousins RJ, Lanningham-Foster L. Regulation of cysteinerich intestinal protein, a zinc finger protein, by mediators of the immune response. J Infect Dis. 2000; 182 Suppl 1: S81-84.

8. Liu S, Stromberg A, Tai HH, Moscow JA. Thiamine transporter gene expression and exogenous thiamine modulate the expression of genes involved in drug and prostaglandin metabolism in breast cancer cells. Mol Cancer Res. 2004; 2: 477-487.

9. Ma XJ, Salunga R, Tuggle JT, Gaudet J, Enright E, McQuary P, Payette T, Pistone M, Stecker K, Zhang BM, Zhou YX, Varnholt H, Smith B, Gadd M, Chatfield E, Kessler J et al. Gene expression profiles of human breast cancer progression. Proc Natl Acad Sci U S A. 2003; 100: 5974-5979.

10. Mackay A, Jones C, Dexter T, Silva RL, Bulmer K, Jones A, Simpson P, Harris RA, Jat PS, Neville AM, Reis LF, Lakhani SR, O'Hare MJ. cDNA microarray analysis of genes associated with ERBB2 (HER2/neu) overexpression in human mammary luminal epithelial cells. Oncogene. 2003; 22: 2680-2688.

11. Chen Y, Miller C, Mosher R, Zhao X, Deeds J, Morrissey M, Bryant B, Yang D, Meyer R, Cronin F, Gostout BS, Smith-McCune K, Schlegel R. Identification of cervical cancer markers by cDNA and tissue microarrays. Cancer Res. 2003; 63: 1927-1935.

12. Groene J, Mansmann U, Meister R, Staub E, Roepcke S, Heinze M, Klaman I, Brummendorf T, Hermann K, Loddenkemper C, Pilarsky C, Mann B, Adams HP, Buhr HJ, Rosenthal A. Transcriptional census of 36 microdissected colorectal cancers yields a gene signature to distinguish UICC II and III. Int J Cancer. 2006; 119: 1829-1836.

13. Santin AD, Zhan F, Bignotti E, Siegel ER, Cane S, Bellone S, Palmieri M, Anfossi S, Thomas M, Burnett A, Kay HH, Roman JJ, O’Brien TJ, Tian E, Cannon MJ, Shaughnessy J, Jr. et al. Gene expression profiles of primary HPV16- and HPV18-infected early stage cervical cancers and normal cervical epithelium: identification of novel candidate molecular markers for cervical cancer diagnosis and therapy. Virology. 2005; 331: 269-291.

14. Terris B, Blaveri E, Crnogorac-Jurcevic T, Jones M, Missiaglia E, Ruszniewski P, Sauvanet A, Lemoine NR. Characterization of gene expression profiles in intraductal papillary-mucinous tumors of the pancreas. Am J Pathol. 2002; 160: 1745-1754.

15. Wang Q, Williamson M, Bott S, Brookman-Amissah N, Freeman A, Nariculam J, Hubank MJ, Ahmed A, Masters JR. Hypomethylation of WNT5A, CRIP1 and S100P in prostate cancer. Oncogene. 2007; 26: 6560-6565.

16. Balluff B, Rauser S, Meding S, Elsner M, Schone C, Feuchtinger A, Schuhmacher C, Novotny A, Jutting U, Maccarrone G, Sarioglu H, Ueffing M, Braselmann H, Zitzelsberger H, Schmid RM, Hofler $\mathrm{H}$ et al. MALDI Imaging Identifies Prognostic Seven-Protein Signature of Novel Tissue Markers in Intestinal-Type Gastric Cancer. Am J Pathol. 2011; 179: 2720-2729.

17. Birkenmeier EH, Gordon JI. Developmental regulation of a gene that encodes a cysteine-rich intestinal protein and maps near the murine immunoglobulin heavy chain locus. Proc Natl Acad Sci U S A. 1986; 83: 2516-2520.

18. Klein A, Olendrowitz C, Schmutzler R, Hampl J, Schlag PM, Maass N, Arnold N, Wessel R, Ramser J, Meindl A, Scherneck S, Seitz S. Identification of brain- and bonespecific breast cancer metastasis genes. Cancer Lett. 2009; 276: 212-220.

19. Smid M, Wang Y, Klijn JG, Sieuwerts AM, Zhang Y, Atkins D, Martens JW, Foekens JA. Genes associated with breast cancer metastatic to bone. J Clin Oncol. 2006; 24: 2261-2267.

20. Baumhoer D, Riener MO, Zlobec I, Tornillo L, Vogetseder A, Kristiansen G, Dietmaier W, Hartmann A, Wuensch PH, Sessa F, Ruemmele P, Terracciano LM. Expression of 
CD24, P-cadherin and S100A4 in tumors of the ampulla of Vater. Mod Pathol. 2009; 22: 306-313.

21. Zlobec I, Steele R, Terracciano L, Jass JR, Lugli A. Selecting immunohistochemical cut-off scores for novel biomarkers of progression and survival in colorectal cancer. J Clin Pathol. 2007; 60: 1112-1116. 